\title{
Helicobacter pylori associated with a high prevalence of duodenal ulcer disease and a low prevalence of gastric cancer in a developing nation
}

\author{
P J Hu, Y Y Li, M H Zhou, M H Chen, G G Du, B J Huang, H M Mitchell, S L Hazell
}

Affiliated First

Hospital, Sun Yat-Sen University of Medical

Science, People's

Republic of China

$\mathrm{PJ} \mathrm{Hu}$

M H Zhou

M H Chen

First Municipal

People's Hospital of

Guangzhou,

Guangzhou, People's

Republic of China

Y Y Li

G G Du

B J Huang

School of Microbiology

and Immunology,

University of New

South Wales, Sydney,

Australia

H M Mitchell

S L Hazell

Correspondence to:

Dr S L Hazell, School of

Microbiology and

Immunology, University of

New South Wales, Sydney, 2052 Australia.

Accepted for publication 27 May 1994

\begin{abstract}
This study examines the relationship between Helicobacter pylori infection and peptic ulcer disease and gastric cancer - in particular, the presence or absence of bacteria, the grading of gastritis, and the degree of inflammation in the antral and oxyntic mucosae. The grading of gastritis and the detection of $\boldsymbol{H}$ pylori were determined by histology using the Sydney system. Of the 1006 patients examined, $34.5 \%$ had duodenal ulcer disease, $3.5 \%$ gastric ulcer disease, and $2 \%$ with coexistent ulceration. Most patients $(50 \cdot 2 \%)$ were classified as having non-ulcer dyspepsia. Altogether $2 \cdot 4 \%$ of patients had gastric cancer and two further patients had carcinoma in the gastric stump. Of the ulcer disease patients, $87 \cdot 2 \%$ had histological evidence of $\boldsymbol{H}$ pylori infection. After patients who had taken antibiotics or bismuth compounds in the preceding four weeks were excluded, $98.9 \%$ of the duodenal ulcer disease, $100 \%$ of the gastric ulcer disease, and $100 \%$ of the coexistent ulcer disease patients had evidence of $H$ pylori infection. In patients with gastric cancer who had not taken antimicrobial agents in the four weeks before endoscopy, $83.3 \%$ had evidence of $H$ pylori infection. Thus, there was a high rate of duodenal ulcer disease and a low rate of gastric ulcer disease in southern China, an area of low gastric cancer mortality. There was a specific topographical relationship between $H$ pylori, the histological response, and gastroduodenal disease. Our data suggest that the status of a nation as either 'developed' or 'developing' can not be used to predict the upper gastrointestinal disease profile of its population.

(Gut 1995; 36: 198-202)
\end{abstract}

Keywords: Helicobacter pylori, peptic ulcer disease, gastric cancer.

In recent years we have investigated the relationship between Helicobacter pylori infection and upper gastrointestinal disease in the People's Republic of China. In previous reports we have reviewed the relationship between $H$ pylori and gastritis, examined the epidemiology of infection, and briefly addressed the relationship between infection and peptic ulcer diseases. ${ }^{1-3}$ Although there is good current evidence supporting the role of
$H$ pylori in duodenal ulcer disease, ${ }^{4-9}$ the relationship between $H$ pylori infection and gastric ulcer disease has remained relatively neglected. ${ }^{10-13}$

Following a recent study of ours, we found that in southern China $H$ pylori associated gastritis looked similar to that reported in other studies where both the antral and oxyntic mucosae had been investigated. ${ }^{3}$ In this study, however, we noted that in relation to upper gastrointestinal disease, there was a need to examine further the specific topographical relationship between $H$ pylori and its associated histological response. This study aimed to extend our knowledge of the relationship between $H$ pylori infection, peptic ulcer disease, and gastric cancer within a southern Chinese population. In this investigation we have focused on peptic ulcer disease and gastric cancer in relation to the presence or absence of bacteria, the grading of gastritis, and factors such as the degree of inflammation in the antral and oxyntic mucosae.

\section{Methods}

PATIENTS

This study examined 1006 consecutive patients who presented for endoscopic examination at the Affiliated First Hospital, Sun Yat-Sen University of Medical Science, Guangzhou, Peoples Republic of China. All patients were from the local population and were referred to the hospital for the investigation of upper gastrointestinal symptoms of unknown aetiology. The patients were not referred from other endoscopy clinics or selected because of the severity of symptoms. Patients consisted of both outpatients and inpatients from all social strata. Because of the medical system in this region of China, the outpatient population would represent a group similar to that investigated by a private outpatient practice in many parts of the developed world. Follow up patients were excluded from the study. Each patient was asked about their antibiotic intake over the previous four weeks. Informed consent was obtained from each patient. The project conforms to the declaration of Helsinki and was approved by the Director of the Guangzhou Health Bureau on advice from the Scientific Affairs Committee.

\section{ENDOSCOPIC EXAMINATION}

Patients were examined using an Olympus 
Q20 endoscope and the presence of lesions in the gastroduodenal mucosa was noted. Differentiation was made between erosions and true ulcers in the classification of disease. The criteria for inclusion in the ulcer group were a circumscribed break in the mucosa with apparent depth and covered by an exudate as well as those patients with healing ulcers or ulcer scarring. Ulcers located in the stomach or duodenum were classified as gastric and duodenal ulcers respectively. Where ulcers occurred in both the stomach and the duodenum simultaneously, these were classified as coexistent ulcers. Where an ulcer occurred coexistent with gastric malignancy, the patient was classified as being in the gastric cancer group.

BIOPSIES

Jumbo biopsy forceps (FB-25K) were used to collect biopsy specimens from both the oxyntic and antral gastric mucosae. In the antrum, two specimens, one each from the anterior and posterior wall $2 \mathrm{~cm}$ from the pylorus, were taken for histology. Similarly in the body, two biopsy specimens, one each from the anterior and posterior wall, midway between the antralbody junction and cardia, were collected for histology. Specimens were not taken from patients in whom there was a risk of complications such as gastric bleeding.

\section{HISTOLOGY}

Biopsy specimens for histological examination were fixed in $10 \%$ buffered formalin and processed routinely. Paraffin sections $(5 \mu \mathrm{m})$ were cut and stained by haematoxylin and eosin, and for the presence of $H$ pylor $i$ by modified Giemsa stain. Sections were graded for bacteria, inflammation (chronicity), polymorphonuclear leukocytes (activity), atrophy, and intestinal metaplasia in accordance with the recommendations of the working party that developed the Sydney system for the histological grading of gastritis. ${ }^{14}$

\section{STATISTICS}

$\chi^{2}$ analysis with Yates's correction were performed using the SPSS program (SPSS Inc, IL, USA). Where multiple comparisons were performed, the Bonferroni inequality was taken into account to adjust the $\mathrm{p}$ values.

\section{Results}

Examination of the 1006 patients by gastroduodenoscopy showed that $403(40 \%)$, aged from 16 to 70 years, had an endoscopic finding of peptic ulcer disease (348 duodenal ulcer, 35 gastric ulcer, and 20 with coexistant ulceration) (Table I). Most patients, $505(50 \cdot 2 \%)$ aged 17 to 65 years, had no significant endoscopically definable findings and were classified as having non-ulcer dyspepsia (Table I). Twenty four $(2 \cdot 4 \%)$ of the patients were diagnosed as having gastric cancer and were in the age range of 32 to 72 years, with two
TABLE I Diagnosis of disease in the patient population

\begin{tabular}{lcll}
\hline Disease & No (\%) & $\begin{array}{l}\text { Sex ratio } \\
\text { (male:female) }\end{array}$ & $\begin{array}{l}\text { Mean age } \\
(y)\end{array}$ \\
\hline Duodenal ulcer & $348(34 \cdot 5)$ & $2 \cdot 05: 1$ & $42 \cdot 7$ \\
Gastric ulcer & $35(3 \cdot 5)$ & $2 \cdot 89: 1$ & $51 \cdot 0$ \\
Coexistent ulcer & $20(2 \cdot 0)$ & $5 \cdot 67: 1$ & $50 \cdot 5$ \\
Gastric cancer & $24(2 \cdot 4)$ & $2 \cdot 0: 1$ & $53 \cdot 8$ \\
Non-ulcer dyspepsia & $505(50 \cdot 2)$ & $0 \cdot 94: 1$ & $38 \cdot 4$ \\
Peristomal gastritis & $28(2 \cdot 78)$ & $3 \cdot 65: 1$ & $55 \cdot 7$ \\
Stomal ulcer & $2(0 \cdot 2)$ & - & $42 \cdot 5$ \\
Gastric stump & & & \\
$\quad$ carcinoma & $2(0 \cdot 2)$ & - & $52 \cdot 5$ \\
Oesophageal carcinoma & $8(0 \cdot 8)$ & $1: 1$ & $61 \cdot 3$ \\
Other & $34(3 \cdot 4)$ & - & - \\
\hline
\end{tabular}

additional patients aged 50 and 55 years having carcinoma in the gastric stump. The remaining patients aged 39 to 80 years had other disease manifestations, including stomal ulceration, peristomal gastritis, and oesophageal carcinoma (Table I). Except for the non-ulcer dyspepsia group and the oesophageal cancer patients (where men and women were in almost equal proportions) men predominated in the disease groups (Table I).

Of the 937 patients from whom biopsy material was available, 885 were classified as having either ulcer disease, gastric cancer, or non-ulcer dyspepsia (Table II). Three hundred and twenty eight of 376 patients with ulcer disease $(87 \cdot 2 \%)$ had histological evidence of $H$ pylori infection $(87.2 \%$ in duodenal ulcer disease, $90 \%$ in gastric ulcer disease, and $83.3 \%$ in coexistant ulcer disease - gastric plus duodenal ulceration) (Table II). Of the 22 gastric cancer patients from whom biopsy specimens were collected, $16(72 \cdot 7 \%)$ had histological evidence of $H$ pylori infection (Table II).

When patients who had taken antibiotics or bismuth compounds in the four weeks before endoscopy were excluded from the above groups, 308 of $311(99 \%)$ of the ulcer disease patients had evidence of $H$ pylori infection (98.9\% in duodenal ulcer disease, $100 \%$ in gastric ulcer disease, and $100 \%$ in coexistant ulcer disease) (Table II). H pylori infection was evident in 15 of $18(83.3 \%)$ of the gastric cancer group (Table II). There was a significant association between the presence of $H$ pylori and peptic ulcer disease compared with those patients diagnosed as having non-ulcer dyspepsia $\left(\chi^{2}=157 \cdot 35, \mathrm{DF}=1, \mathrm{p}<0.001\right)$.

The grading of gastritis in 642 patients diagnosed as having either peptic ulcer disease or non-ulcer dyspepsia who had not taken antimicrobial agents in the preceding four weeks was determined. Of these patients, 498 of $642(77 \cdot 6 \%)$ had histological evidence of $H$ pylori infection. All of these infected individuals had some degree of inflammation at one

TABLE II Incidence of Helicobacter pylori in principal disease groups ${ }^{\star}$

\begin{tabular}{lcc}
\hline Disease & $\begin{array}{l}\text { No infected/ } \\
\text { total }(\%)\end{array}$ & $\begin{array}{l}\text { No infected/total (\%) } \\
\text { adjusted group } \dagger\end{array}$ \\
\hline Duodenal ulcer & $286 / 328(87 \cdot 2)$ & $271 / 274(98 \cdot 9)$ \\
Gastric ulcer & $27 / 30(90 \cdot 0)$ & $25 / 25(100)$ \\
Coexistent ulcer & $15 / 18(83 \cdot 3)$ & $12 / 12(100)$ \\
Gastric cancer & $16 / 22(72 \cdot 7)$ & $15 / 18(83 \cdot 3)$ \\
Non-ulcer dyspepsia & $247 / 467(52 \cdot 9)$ & $190 / 331(57 \cdot 4)$ \\
\hline
\end{tabular}

^Biopsy specimens contraindicated in 69 cases. †Adjusted to exclude patients who had a record of taking bismuth or antibiotics in the four weeks before endoscopy. 
TABLE III Histological grading of gastritis in relation to Helicobacter pylori status in ulcer and non-ulcer dyspepsia patients who had not taken antimicrobial agents before endoscopy

\begin{tabular}{llll}
\hline \multirow{2}{*}{$\begin{array}{l}\text { Helicobacter } \\
\text { pylori }\end{array}$} & \multicolumn{4}{l}{ Chronic gastritis } \\
\cline { 2 - 4 } & Mild & Moderate-severe & Total (\%) \\
\hline Positive & 16 & 482 & $498(84 \cdot 7)$ \\
Negative & 82 & 8 & $90(15 \cdot 3)$ \\
Total $(\%)$ & $98(16 \cdot 7)$ & $490(83 \cdot 3)$ & $588(100)$
\end{tabular}

^Fifty eight patients negative for $H$ pylori had no evidence of gastritis.

or more sites in the stomach. Pangastritisantral predominant was the most common gastritis presentation in $365(73.3 \%)$ of this group of $H$ pylori positive patients, followed by antral only gastritis (13.9\%) and uniform pangastritis $(11 \cdot 2 \%)$. In the site where the gastritis was most predominant, $96.3 \%$ of this group of 498 patients had chronic gastritis graded as moderate to severe (Table III). Of the 144 of $642(22.4 \%)$ patients in the $H$ pylori negative group, 90 had some degree of inflammation at one or more sites in the stomach. This gastritis was graded as mild in 82 of $90(91 \cdot 1 \%)$ cases (Table III) and was usually confined to the antrum $(80 \%)$. There was a significant difference between the severity of gastritis in the $H$ pylori infected group compared with the uninfected group $\left(\chi^{2}=417 \cdot 71, \quad \mathrm{DF}=1\right.$, $\mathrm{p}<0.001$ )

Of the 328 duodenal ulcer disease patients from whom biopsy specimens had been taken, the topography of gastritis was pangastritisantral dominant in $236(71.9 \%)$, antral gastritis in $16.8 \%$, and uniform pangastritis in $11.3 \%$ (Table IV). Of the 30 gastric ulcer disease patients, the topography of gastritis was pangastritis-antral dominant in $13(43.3 \%)$, uniform pangastritis in $11(36.7 \%)$, pangastritis-body dominant in four $(13.3 \%)$, and

TABLE IV Topography of gastritis in relation to gastroduodenal disease

\begin{tabular}{lcccc}
\hline \multicolumn{5}{l}{ Disease state (no (\%)) } \\
\cline { 2 - 5 } Site of gastritis & $\begin{array}{l}\text { Duodenal ulcer } \\
(D U)\end{array}$ & $\begin{array}{c}\text { Gastric ulcer } \\
(G U)\end{array}$ & $\begin{array}{l}\text { Coexistent ulcer } \\
(G U \text { plus DU) }\end{array}$ & $\begin{array}{l}\text { Gastric } \\
\text { cancer }\end{array}$ \\
\hline Antral only & $55(16 \cdot 8)$ & $2(6 \cdot 7)$ & $2(11 \cdot 1)$ & $2(9 \cdot 1)$ \\
Pangastritis - antral predominant & $236(72 \cdot 0)$ & $13(43 \cdot 3)$ & $12(66 \cdot 7)$ & $13(59 \cdot 1)$ \\
Pangastritis & $37(11 \cdot 3)$ & $11(36 \cdot 7)$ & $4(22 \cdot 2)$ & $6(27 \cdot 3)$ \\
Pangastritis - body predominant & $0(0)$ & $4(13 \cdot 3)$ & $0(0)$ & $1(4 \cdot 5)$ \\
Body only & $0(0)$ & $0(0)$ & $0(0)$ & $0(0)$ \\
Normal & $0(0)$ & $0(0)$ & $0(0)$ & $0(0)$ \\
Total & 328 & 30 & 18 & 22 \\
\hline
\end{tabular}

TABLE V Topography of atrophy in relation to gastroduodenal disease

\begin{tabular}{|c|c|c|c|c|c|c|}
\hline \multirow[b]{2}{*}{$\begin{array}{l}\text { Distribution } \\
\text { of atrophy }\end{array}$} & \multirow[b]{2}{*}{$\begin{array}{l}\text { Severity } \\
\text { of atrophy }\end{array}$} & \multicolumn{5}{|c|}{ Disease state (no (\%)) } \\
\hline & & $\begin{array}{l}\text { Duodenal } \\
\text { ulcer }\end{array}$ & $\begin{array}{l}\text { Gastric } \\
\text { ulcer }\end{array}$ & $\begin{array}{l}\text { Coexistent } \\
\text { ulcer }\end{array}$ & $\begin{array}{l}\text { Gastric } \\
\text { cancer }\end{array}$ & $N U D$ \\
\hline \multirow[t]{2}{*}{ Antral only } & Moderate & $20(6 \cdot 1)$ & $5(16 \cdot 7)$ & $3(18 \cdot 75)$ & $1(4 \cdot 5)$ & $10(2 \cdot 1)$ \\
\hline & Severe & - & - & - & - & - \\
\hline \multirow[t]{2}{*}{ Body only } & Moderate & - & - & - & - & - \\
\hline & Severe & - & - & - & - & \\
\hline \multirow[t]{2}{*}{ Antral predominant } & Moderate & - & $3(10)$ & - & $1(4 \cdot 5)$ & $2(0 \cdot 4)$ \\
\hline & Severe & - & - & - & $2(9 \cdot 1)$ & - \\
\hline \multirow[t]{2}{*}{ Body predominant } & Moderate & - & - & - & $1(4 \cdot 5)$ & - \\
\hline & Severe & - & - & - & & \\
\hline \multirow[t]{2}{*}{ Uniform } & Moderate & - & - & - & $1(4 \cdot 5)$ & $3(0 \cdot 6)$ \\
\hline & Severe & - & - & & $2(9 \cdot 1)$ & - \\
\hline $\begin{array}{l}\text { No atrophy } \\
\text { Total with atrophy }\end{array}$ & & $\begin{array}{c}308(93 \cdot 9) \\
20 / 328 \\
(6 \cdot 1)\end{array}$ & $\begin{array}{c}22(73 \cdot 3) \\
8 / 30 \\
(26 \cdot 7)\end{array}$ & $\begin{array}{c}13(81 \cdot 25) \\
3 / 16 \\
(18 \cdot 75)\end{array}$ & $\begin{array}{c}14(63 \cdot 6) \\
8 / 22 \\
(36 \cdot 4)\end{array}$ & $\begin{array}{c}452(96 \cdot 8) \\
15 / 467 \\
(3 \cdot 2)\end{array}$ \\
\hline
\end{tabular}

NUD=non-ulcer dyspepsia. antral only gastritis in two cases $(6 \cdot 7 \%)$ (Table IV). Where there was coexistant ulceration (gastric plus duodenal), the topography of gastritis tended to be more antral than in gastric ulcer disease, whereas in gastric cancer the topography of gastritis was similar to that seen in gastric ulcer disease (Table IV). For the purposes of statistical analysis, the antral and antral predominant groups were combined, as were the body and body predominant groups, giving three broad groups (antral/antral predominant, pangastritis, and body/body predominant). Based on this classification, there was a significant difference between one or more of the disease states (duodenal ulcer, gastric ulcer, coexistant ulcer, and gastric cancer) in relation to the topography of gastritis $\left(\chi^{2}=62 \cdot 44, \mathrm{DF}=6, \mathrm{p}<0 \cdot 001\right)$. There was, however, no significant difference seen between the topography of gastritis in the gastric ulcer, gastric cancer, and coexistant ulcer groups $\left(\chi^{2}=5.491, \mathrm{DF}=4, \mathrm{p}=0.482-\right.$ adjusted for Bonferroni inequality). Thus, it may be concluded that there was a significant difference between the topography of gastritis in cases of duodenal ulcer disease compared with the three other disease groups.

Atrophic changes were noted most commonly in cases of gastric cancer (Table V). Four of 22 gastric cancer patients $(18 \cdot 2 \%)$ had severe atrophy occurring either predominantly in the antrum or uniformly throughout the stomach. A further $18 \cdot 2 \%$ of the gastric cancer patients had moderate atrophy ranging in distribution from the antrum to uniformly throughout the stomach. Moderate atrophy was noted in $6.1 \%$ of patients with duodenal ulcer disease, $26.7 \%$ of patients with gastric ulcer disease, and $18.75 \%$ of patients with coexistant ulceration. Atrophy was rare in cases of non-ulcer dyspepsia (Table V).

\section{Discussion}

Whereas there are numerous reports confirming the relationship between $H$ pylori infection and duodenal ulcer disease, ${ }^{4-9}$ data in relation to gastric ulcer disease is not as abundant. In addition, while the recent data on the association between $H$ pylori infection and gastric cancer is sufficiently strong for us to claim that a link exists between the two, ${ }^{15-28}$ it should be noted that association is the weakest test of an hypothesis. Further confirmatory studies are required.

This study aimed to investigate the relationship between infection with the gastric bacterium $H$ pylori and significant gastroduodenal pathology in a patient population from southern China. In addition, a further examination of the relationship between infection, disease, and the presentation of gastritis was undertaken. Histology alone was used to assess the presence or absence of $H$ pylori as we have previously shown a high specificity and sensitivity using this approach. ${ }^{3}$

This study has confirmed the strong association between $H$ pylori infection and duodenal ulcer disease. Indeed, when we looked at the patient group in whom a recent history of 
antimicrobial intake had been excluded, the association between infection and disease was almost absolute. Further, the prevalence of duodenal ulcer disease in this patient population was high $(\sim 35 \%)$ by world standards, consistent with previous comparisons between centres such as Hong Kong and Sydney, Australia. ${ }^{29}$

In Guangdong province, $90 \%$ of the gastric ulcer patients had evidence of $H$ pylori infection. When we again excluded those with a recent history of antimicrobial ingestion, the data showed that all gastric ulcer patients were infected. In contrast, in many studies in developed countries, $H$ pylori has been associated with only about $70 \%$ of gastric ulcers. ${ }^{10-13} \mathrm{~A}$ high proportion of patients with gastric ulceration not associated with $H$ pylori have, however, been found to be taking non-steroidal antiinflammatory drugs (NSAIDs). ${ }^{30-33}$ In Guangdong province the ingestion of NSAIDs is not widespread: in many respects in relation to gastric ulcer disease, therefore, it is perhaps a 'cleaner' population. This may be a characteristic of this region of the world, as Indochinese migrants living in Australia tend to ingest less NSAIDs than Australian born inhabitants, yet have a high incidence of ulcer disease. ${ }^{34}$ In conjunction with the recent treatment studies of Graham et $a l,{ }^{13}$ the implication to be drawn from the southern China data is that in the absence of NSAID ingestion, $H$ pylori should be considered the single most important contributor to the genesis of gastric ulceration.

Burnstein et $a l^{35}$ stated that in developed countries infection with $H$ pylori induces more peptic ulcer disease than gastric cancer, with the reverse being true in the developing world. Whereas this may be true in relation to the Peruvian population studied by Burnstein's group compared with Europeans, it cannot be accepted as a general principle. Even allowing for probable patient selection bias, there was a significantly higher prevalence of duodenal ulcer disease in our southern Chinese patient group $(34.5 \%)$ than in either the Peruvian $(5.2 \%)$ or the European country groups $(11.6 \%)$ studied by Burnstein et al ( $\chi^{2}$, $\mathrm{p}<0.001)$, and a higher ratio of duodenal ulcer disease to gastric ulcer disease (China 10:2:1, Peru 1·2:1, Europe 2:1). The prevalence of gastric ulcer was similar, if not slightly lower, than that seen in both Peruvian patients and those from Europe. In our series, the prevalence of gastric cancer $(2 \cdot 4 \%)$ was intermediate to that seen in the Peruvian patients and those from Europe. ${ }^{35}$ The finding of a lower rate of gastric cancer in our series compared with Peru is consistent with the knowledge that Guangdong province in southern China is an area of relatively low gastric cancer mortality by Chinese standards ( 8.3 deaths $/ 100000$ (age standardised-world)). ${ }^{36} 37$ Our previous studies in southern China, however, have shown the overall prevalence of $H$ pylori to be $44.2 \%$, with infection rates of $23 \%$ in children under 5 years. ${ }^{2}$ These rates are comparable with those reported by Klein et al in Peru. ${ }^{38}$ Thus, based on such comparisons, we found no absolute correlation between the prevalence of $H$ pylori infection in a population and the profile of upper gastrointestinal disease.

The topography of gastritis and the development of atrophy, intestinal metaplasia, and dysplasia seem to be important factors associated with gastric cancer of Lauren's intestinal type. ${ }^{39-43}$ Sipponen has noted that gastritis of different topographic types is broadly associated with different gastrointestinal disease states, and that gastric and duodenal ulcers are extremely rare in patients in whom the gastritis accompanies severe atrophic changes in the corpus mucosa. ${ }^{42}$ In this study there was a lack of extensive atrophy in the patient population; including the gastric cancer patients, in whom only $36 \%$ had evidence of gastric atrophy. Distinct topographical patterns were noted for the gastritis in gastric cancer and gastric ulcer patients compared with duodenal ulcer patients. Pangastritis-antral predominant and antral only gastritis predominated in the duodenal ulcer patients; these forms occurring in almost $89 \%$ of patients. In the gastric ulcer patients, pangastritis of various forms was found in just over $93 \%$ of patients. A similar pattern to this was seen in the gastric cancer patients.

As we and others have asserted in the past, levels of gastric acidity may influence the distribution of $H$ pylori or gastritis, or both, which in turn may influence the disease profile. $^{34244-47}$ Factors leading to gastric cancer may tend to change the pattern of colonisation of the bacterium and the topography of gastritis and thereby decrease the incidence of duodenal ulcer disease. Given that atrophic gastritis and gastric atrophy precede the development of a high proportion of gastric cancers, we suggest that in areas where there is a high prevalence of $H$ pylori and a high incidence of duodenal ulcer disease, important co-factors required for the development of atrophy, intestinal metaplasia and gastric cancer may occur less commonly. Where such co-factors are present, decreased acid output associated with atrophic changes may lead to a significant decrease in the incidence of duodenal ulcer disease.

In conclusion, we have found a high rate of duodenal ulcer disease and a relatively low rate of gastric ulcer disease in an area of low gastric cancer mortality in southern China. We have also shown a topographical relationship between $H$ pylori, the inflammatory response, and gastroduodenal disease. Our data indicate that a high prevalence of $H$ pylori infection will lead to a high overall incidence of upper gastrointestinal disease, however, the form of such disease may be dictated by key environmental triggers.

This work was supported in part by a grant from the International Development Program of Australian Colleges and Universities and the National Health and Medical Research Council of Australia. Some of the data in this paper have been previously presented in China.

$1 \mathrm{Li} \mathrm{YY,} \mathrm{Hu} \mathrm{PJ,} \mathrm{Du} \mathrm{GG,} \mathrm{Hazell} \mathrm{SL.} \mathrm{The} \mathrm{prevalence} \mathrm{of}$ Helicobacter pylori infection in the People's Republic of China. Am 7 Gastroenterol 1991; 86: 446-9.

2 Mitchell HM, Li YY, Hu PJ, Liu Q, Chen M, Du GG, et al. Epidemiology of Helicobacter pylori in Southern China identification of early childhood as the critical period for acquisition. F Infect Dis 1992; 166: 149-53.

$3 \mathrm{Hu}$ PJ, Li YY, Mitchell HM, Zhou MH, Chen MH, Du 
GG, et al. Oxyntic and antral gastritis in the People's Republic of China: Diagnosis and relationship to Helicobacter pylori. Am F Gastroenterol 1992; 87: 741-5.

4 Marshall BJ, Goodwin CS, Warren JR, Murray R, Blincow ED, Blackbourn SJ, et al. Prospective double-blind trial of duodenal ulcer relapse after eradication of Campylobacter pylori. Lancet 1988; ii: 1437-42.

5 Coghlan JG, Gilligan D, Humphries H, McKenna D, Dooley C, Sweeney E, et al. Campylobacter pylori and recurrence of duodenal ulcers - a 12 month follow-up recurrence of duodenal ulcers

6 Graham DY. Treatment of peptic ulcers caused by Hraham DY. Treatment of peptic ulcers caused by Nanivadekar SA, Sawant PD, Patel HD, Shroff CP, Popat Nanivadekar SA, Sawant PD, Patel HD, Shroff CP, Popat
UR, Bhatt PP. Association of peptic ulcer with Helicobacter pylori and the recurrence rate. A three year follow-up study. F Assoc Physicians India 1990; 1: 703-6.

8 Rauws EA. Campylobacter pylori as possible factor in peptic ulcer recurrence. Acta Gastroenterol Belg 1989; 52: 320-3

9 Yeomans ND. Bacteria in ulcer pathogenesis. Baillieres Clin Gastroenterol 1988; 2: 573-91.

10 Leung KM, Hui PK, Chan WY, Thomas TMM. Helicobacter pylori-related gastritis and gastric ulcer - a continuum of progressive epithelial degeneration. $A m \mathscr{f}$ Continuum of progressive epithel 1992; 98: 569-74.

11 Bell GD, Powell KU. Eradication of Helicobacter pylori and its effect in peptic ulcer disease. Scand $\mathcal{F}$ Gastroenterol 1993; 28 (suppl 196): 7-11.

12 Hui PK, Chan WY, Cheung PS, Chan JKC, Ng CS. Pathologic changes of gastric mucosa colonized by Helicobacter pylori. Hum Pathol 1992; 23: 548-56.

13 Graham DY, Lew GM, Klein PD, Evans DG, Evans DJ, Saeed ZA, et al. Effect of treatment of Helicobacter pylori infection on the long-term recurrence of gastric or duodenal ulcer, a randomized, controlled study. Ann Intern Med 1992; 116: 705-8.

14 Price AB. The Sydney system: Histological division. $f$ Gastroenterol Hepatol 1991; 6: 209-22.

15 Correa P, Ruiz B. Campylobacter pylori and gastric cancer. In: Rathbone BJ, Heatley RV, eds. Campylobacter pylori
and gastroduodenal disease. London: Blackwell Scientific and gastroduodenal disease.

16 Buruk F, Berberoglu U, Pak I, Aksaz E, Celen O. Gastric cancer and Helicobacter pylori infection. Br f Surg 1993; 80: $378-9$.

17 Correa P, Fox J, Fontham E, Ruiz B, Lin YP, Zavala D, et al. Helicobacter pylori and gastric carcinoma. Serum antibody prevalence in populations with contrasting cancer risks. Cancer 1990; 66: 2569-74.

18 Tatsuta $M$, Iishi H, Okuda S, Taniguchi H, Yokota Y. The association of Helicobacter pylori with differentiated-type early gastric cancer. Cancer 1993; 72: 1841-5.

19 Forman D, Newell DG, Fullerton F, Yarnell JW, Stacey $\mathrm{AR}$, Wald $\mathrm{N}$, et al. Association between infection with AR, Wald N, et al. Association between infection with Helicobacter pylori and risk of gastric cancer: evidence
from a prospective investigation. $B M Y 1991 ; 302: 1302-5$.

20 Forman D. Helicobacter pylori infection: a novel risk factor in the etiology of gastric cancer. $\mathcal{F}$ Natl Cancer Inst 1991; 83: $1702-3$.

21 Fox JG, Correa P, Taylor NS, Zavala D, Fontham E, Janney F, et al. Campylobacter pylori-associated gastritis and immune response in a population at increased risk of
gastric carcinoma. $A m \mp$ Gastroenterol $1989 ; 84: 775-81$.

22 Jankowski J. Helicobacter pylori infection and gastric cancer. BMF 1991; 302: 1534 .

23 Nomura A, Stemmermann GN. Helicobacter pylori and gastric cancer. Fournal of Gastroenterology and Hepatology gastric cancer. Fournd

24 Parsonnet J, Vandersteen D, Goates J, Sibley RK, Pritikin J, Chang Y. Helicobacter pylori infection in intestinal- and diffuse-type gastric adenocarcinomas. $\mathcal{F}$ Natl Cancer Inst 1991; 83: 640-3.

25 Scott N, Lansdown M, Diament R, Rathbone B, Murday V, Wyatt JI, et al. Helicobacter gastritis and intestinal metaplasia in a gastric cancer family. Lancet 1990; 1: 728.

26 Sipponen P, Kosunen TU, Valle J, Riihela M, Seppala K.
Helicobacter pylori infection and chronic gastritis in gastric cancer. $\mathcal{F}$ Clin Pathol 1992; 45: 319-23.

27 Forman D, Coleman M, Debacker G, Eider J, Moller H, Damotta LC, et al. An international association between Helicobacter pylori infection and gastric cancer. Lancet 1993; 341: 1359-62.

28 Forman D. Helicobacter pylori infection and gastric carcinogenesis. European fournal of Gastroenterology and Hepatology 1992; 4 (suppl 2): S31-5.

29 Lam SK. Peptic ulcer: from epidemiology to cause. fournal of Gastroenterology and Hepatology 1989; 2: 1-6.

30 Graham DY, Smith JL. Gastroduodenal complications of chronic NSAID therapy. Am $\mathcal{f}$ Gastroenterol 1988; 83: $1081-4$

31 Soll AH, Weinstein WM, Kurata J, McCarthy D. Nonsteroidal anti-inflammatory drugs and peptic ulcer disease. Ann Intern Med 1991; 114: 307-19.

32 Wallace JL. Gastric ulceration - critical events at the neutrophil endothelium interface. Canadian fournal of Physiology and Pharmacology 1993; 71: 98-102.

33 Schubert TT, Bologna SD, Nensey Y, Schubert AB, Mascha EJ, Ma CK. Ulcer risk factors - interactions between Helicobacter pylori infection, nonsteroidal use, and age. Am f Med 1993; 94 (4): 413-8.

34 Kolt SD, Kronborg IJ, Yeomans ND. High prevalence of duodenal ulcer in Indochinese immigrants attending an duodenal ulcer in Indochinese immigrants attending an and Hepatology 1993; 8: 128-32.

35 Burstein M, Monge E, Leon BR, Lozano R, Berendson R, Gilman RH, et al. Low peptic ulcer and high gastric cancer prevalence in a developing country with a high prevalence of infection by Helicobacter pylori. $f$ Clin Gastroenterol 1991; 13: 154-6.

36 Editorial committee for the atlas of cancer mortality in the People's Republic of China. Atlas of cancer mortality in the People's Republic of China. Beijing: China Map Press, 1973.

37 Chen JS, Campbell TC, Li JY, Peto R. Diet, lifestyle and mortality in China. A study of the characteristics of 65 Chinese countries. Oxford: Oxford University Press, 1990.

38 Klein PD, Graham DY, Gaillour A, Opekun AR, Smith EO. Water source as risk factor for Helicobacter pylori EO. Water source as risk factor for Helicobacter pylori

39 Correa P. Human gastric carcinogenesis - a multistep and multifactorial process - first american cancer society award lecture on cancer epidemiology and prevention. Cancer Res 1992; 52: 6735-40.

40 Lauren PA, Nevalainen TJ. Epidemiology of intestinal and diffuse types of gastric carcinoma - a time-trend study in Finland with comparison between studies from high-risk and low-risk areas. Cancer 1993; 71: 2926-33.

41 Lauren P. The two histological main types of gastric carcinoma: diffuse and so-called intestinal-type carcinoma: an attempt at a histo-clinical classification. Acta Pathologica et Microbiologica Scandinavica 1965; 64: 31-49.

42 Sipponen $P$. Natural history of gastritis and its relationship to peptic ulcer disease. Digestion 1992; 51 (suppl 1): $70-5$.

43 Sipponen P, Seppala K. Gastric carcinoma - failed adaptation to Helicobacter pylori. Scand $\mathcal{F}$ Gastroenterol 1992; 27 (suppl 193): 33-8.

44 Hazell SL, Hennessy WB, Borody TJ, Carrick J, Ralston M, Brady L, et al. Campylobacter pyloridis gastritis II: Distribution of bacteria and associated inflammation in the gastroduodenal environment. $A m \mathcal{f}$ Gastroenterol 1987; 82: 297-301.

45 Stolte M, Eidt S, Ohnsmann A. Differences in Helicobacter pylori associated gastritis in the antrum and body of the stomach. $Z$ Gastroenterol 1990; 28: 229-33.

46 Hui WM, Lam SK, Ho J, Lai CL, Lok AS, Ng MM, et al. Effect of omeprazole on duodenal ulcer-associated antral gastritis and Helicobacter pylori. Dig Dis Sci 1991; 36: 577-82.

47 Fich A, Talley NJ, Shorter RG, Phillips SF. ZollingerEllison syndrome. Relation to Helicobacter pyloriassociated chronic gastritis and gastric acid secretion. Dig Dis Sci 1991; 36: 10-4. 